\title{
The diversity of the Brazilian regional Audit Courts on government auditing*
}

\author{
André Feliciano Lino \\ Universidade de São Paulo, Faculdade de Economia, Administração e Contabilidade de Ribeirão Preto, Departamento de Contabilidade, \\ Ribeirão Preto, SP, Brazil \\ Email: aflino@usp.br
}

\section{André Carlos Busanelli de Aquino}

Universidade de São Paulo, Faculdade de Economia, Administração e Contabilidade de Ribeirão Preto, Departamento de Contabilidade, Ribeirão Preto, SP, Brazil

Email: aaquino@usp.br

Received on 04.25.2016 - Desk acceptance on 05.02.2016 - $3^{\text {rd }}$ version approved on 06.18.2017 - Ahead of print on 11.06.2017

\begin{abstract}
Currently, the 33 regional audit courts are responsible to monitor the public financial management cycle for states and municipalities and to judge the compliance of governors' acts to the laws regarding procurement and civil servants' employment from more than 20,000 governmental entities under their jurisdiction. This article aims to analyze the diversity of internal configuration of these regional audit courts and to discuss the potential associations with the financial auditing quality their teams usually run. We conducted interviews with external auditors and IT directors from 18 courts, followed by triangulation to official documents from the audit courts, such as audit manuals and activities reports. The audit quality drivers were identified within the governmental auditing literature, supporting the evidences collected by the interviews content analysis. Despite all regional auditing bodies in Brazil were based on the Napoleonic model, the analysis indicates the identified configurations vary according to the team's organization and size, auditor rotation and use of data reporting systems. The discussion shows that dissimilarities on the courts' configurations, as they are responsible to audit a specific country area, will contribute to a different coercion level on fiscal and accounting issues to state and municipalities, due a combination of characteristics which could mitigate or improve the audit quality. This paper additionally suggests some precautions, based on the organization alignment literature, for the use of proxies to control audit quality effects in the public finance studies in Brazil.
\end{abstract}

Keywords: governmental audit, Courts of Accounts, external control, audit quality, public sector accounting.

Correspondence address:

André Feliciano Lino

Universidade de São Paulo, Faculdade de Economia, Administração e Contabilidade de Ribeirão Preto,

Departamento de Contabilidade

Avenida Bandeirantes, 3900 - CEP: 14040-900

Monte Alegre - Ribeirão Preto - SP - Brasil

*Paper presented at the X ANPCONT Congress, Ribeirão Preto, SP, Brazil, June 2016. 


\section{INTRODUCTION}

"... the National Council of Courts of Accounts is the cornerstone for the definition of a national system that integrates the 34 Courts of Accounts, with the capacity to make the Courts of Accounts speak the 'same language' and to serve the interest of the society, because Brazil 'cannot afford to have islanded bodies". Bruno Dantas, Minister of the Brazilian Supreme Audit Institution (Tribunal de Contas da União - TCU), 2015, at an event of the Association of Members of the Brazilian Courts of Accounts in São Paulo.

The proposal to create a National Council of Courts of Accounts (CNTC in Brazilian Portuguese) is not new: the issue has been debated in the Federal Senate and in the press since proposals for constitutional amendments in 2007. Similar to the successful creation of the National Justice Council and the National Council of the Public Prosecution, the new national council would bring uniformity to procedural norms, guiding audit professionals practices, and acting as a centralized administrative oversight of the Courts of Accounts in the country. In addition to the various understandings that arise regarding the application of fiscal regulation, for example in the interpretation of limits to the use of unpaid commitments or the inclusion of some charges in the limits of personnel expenditures imposed by the Fiscal Responsibility Law (LRF), the rigidity observed in the scrutiny and imposition of penalties also varies with the Court of Accounts. Finally, as freely presented by Senator Humberto Costa to those appointed as Ministers to the Brazilian Supreme Audit Institution (TCU) in the Committee on Economic Matters of the Federal Senate in 2014, cooptation cases of Counselors of State Courts of Account that act in defense of governors given the political indication are well known. The diversity in the composition and practices of the Courts of Accounts lead to different applications of fiscal, financial and accounting regulation in the country.

In the Brazilian context, the 33 State Courts of Accounts, Municipalities and Federal District (CAs) compose the control network on the public administration, which is also formed by the Legislative Branch, Public Prosecutor's Office, Superior Electoral Court and the SAI (Speck, 2011). The mandate of government audit organizations in Brazil is identified in Articles 70 to 75 of the Federal Constitution of 1988, which place the TCU and CAs as technical organizations auxiliary of the Legislative Branch. However, not only accountability arise from the joint enforcement capacity of the control network, but the diffusion of Public Financial Management (PFM) cycle reforms is also induced by the understanding of the audit bodies, since they will exercise enforcement of the regulation in force, including fiscal matters.

The dynamism of PFM regulation in Brazil has intensified since 1988, demanding the CAs to review their understandings and procedures demanding the adoption of the innovations by audited entities. Both the new planning instruments, such as the Multi-year Plan (PPA), the Annual Budget Guidelines Law (LDO), and the Appropriation Bill or Annual Budget Law (LOA), the use of physical and fiscal targets, the increasing of the transparency level in the budget process became focus of auditing by CAs. The same with annual account reports by CAs which now requires the preparation of reports on budget execution and on the existence and conditions of the municipality's internal control. Finally, the CAs began issuing their guidelines on convergence to International Public Sector Accounting Standards (IPSAS), which imposed a standardized chart of accounts and the adoption of specific accounting policies by the municipalities.

All of these reforms originated from the central government, designed at Esplanada dos Ministérios' in Brasilia or at the National Congress, go through a long process until they are institutionalized, that is, embedded at the most operational levels of governments (Andrews, 2013). In this process, audit organizations (SAIs or regional audit bodies) are responsible for encouraging reforms. These independent technical bodies are responsible for external control in the PFM cycle (Stapenhurst \& Titsworth, 2001) and run three relevant functions: (i) translation and reduction of the ambiguity of new values, concepts, formulas and limits present in the new practice; (ii) dissemination of new understandings of regulation, using its capillarity and access to the various organs of the federation entities; and (iii) enforcement over the new practice, imputing punishment for misconduct. It is not expected that PFM reforms generate positive impacts on public finance without the inductive role of CAs. Therefore, the PFM reforms that challenge CAs to review their understandings and procedures depend on them to be institutionalized by governments.

Since their creation, the basic structure, organization and mandate of CAs are anchored in the Napoleonic model. It was maintained by the 1988 Constitution and in the organization of TCU (in its various versions since 1896). In the Napoleonic model, the CA operates in two layers: a technical one, formed by audit teams, and a judging one, made up of Counselors, with technicalpolitical orientation (Arantes, Abrucio \& Teixeira, 2005). 
Despite the common basic structure, there is still room for discretion to organize internal activities, given the autonomy of CAs (for example, the policy of allocating audit activities to teams, the use of data reporting systems for collecting data from the audited entities, policies for personnel qualification). Such differences can influence the quantity and quality of audits, interfering with the effectiveness of each CA, which justifies the debate about the need to create the National Council of Courts of Accounts, as already mentioned.

Organizations such as the Association of Members of the Brazilian Courts of Accounts (Atricon) and Instituto Rui Barbosa (IRB) carry out actions to reduce the heterogeneity of CAs in the absence of the National Council Courts of Accounts . In 2002, Atricon mapped the CAs characteristics and identified deficiencies as gap on IT capabilities, culminating to the launch of PROMOEX (Program for Modernization of the External Control System of the States, Federal District and Brazilian Municipalities). Promoex aimed to develop 28 participating CAs and was held from 2006 to 2012, with the support from the Inter-American Development Bank. Recently, Atricon has leading similar actions include the development of the Government Auditing Standards (NAGs), the current Brazilian Public Sector Auditing Standards (NBASP), a portal of good practices to be used as a benchmark to all CAs, and a CA's performance measurement framework. Finally, Atricon is encouraging the adoption of the Municipal Management Effectiveness Index (IEGM) by all CAs in Brazil.

Unlike public sector practitioners, who has already recognized the impact of CAs diversity, the role of auditing in government performance literature is rarely addressed (Rosa, Morote \& Prole, 2014). Studies on regional government audit organizations are rare (Melo \& Pereira, 2013). Also, there is lack of discussion on the differences of these organizations- one exception is Wehner (2003). The previous studies seek to identify how external factors over which audit organizations do not have influence ( such as political factors or size of the budget) would affect the performance of their activities in regional and local governments (Melo \& Pereira, 2013). However, they ignore internal factors to these organizations under which there is discretion and autonomy, such as the execution of audit processes or the use of data reporting systems to collect data from audited entities. One of the exceptions is the study by Melo, Pereira, and Souza (2014), which pointed out the positive effect of CA productivity (number of audits performed by each court in a given year by the number of organs) in reducing propensity to use unpaid commitments by State government. Furthermore, previous studies on public finance in Brazil do not consider the role of CAs, especially those involving the impact of the Fiscal Responsibility Law on municipalities (Gerigk, Clemente \& Taffarel, 2010; Santos \& Alves, 2011; Santolin, Jayme Jr \& Reis, 2009). Given the role of CAs in the fiscal dynamics of regional and local governments, the results of these studies would gain greater internal validity by controlling the coercive effect that CAs eventually exert on audited entities.

This research aims to analyze the diversity of internal configuration of regional audit courts in Brazil and to discuss the potential associations with the financial auditing quality their teams usually run. Also, implications of the findings for public finance research in Brazil are suggested. In addition to the institutional differences of the counselors dynamics in CAs (political layer), usually politically oriented as described by Loureiro, Teixeira and Moraes (2009), we specifically discuss the differences in the technical layer. External control agents from 18 Courts of Accounts were interviewed all over the country. The interviews were triangulated with documents provided by the CAs.

Next, we present the regional government audit models and the audit quality literature on governments. After the methodology, we present the identified diversity of observed CAs. Finally, we discuss the implications of a such diversity and offer final comments. 


\section{AUDIT MODELS IN THE PUBLIC SECTOR}

Audit procedures are relevant part of public financial management (PFM) cycle ) to guarantee the legality and efficiency of government actions. The PFM cycle is a series of institutional routines that guide the behavior of bureaucracy in the use of the allocated resources to deliver public policies (Campos \& Pradhan, 1996). Routines can be separated into steps (for didactic purposes), from budget preparation and resource management to public accountability, comprising internal or external control (Andrews, 2007). At each stage of the PFM cycle, various governmental and civil society actors produce and use information (Moynihan \& Andrews, 2010). At the stage of the PFM cycle that occurs within the organization, internal auditors and part of Internal Control work; auditors from auditing organizations work externally in central, regional and local governments, responsible for External Control.

External audit organizations can be classified into three major general models: (i) Westminster model, (ii) Collegiate model and (iii) Napoleonic model (Stapenhurst \& Titsworth, 2001). In the Westminster Anglo-Saxon model, adopted in the United Kingdom, in the 53 former British colonies, and in countries such as Chile and Peru, the General Auditor centralizes decision-making powers over all matters of the body. Professionals with backgrounds in economics and finance are predominant, and audit work has a financial bias with less emphasis on legality (Stapenhurst \& Titsworth, 2001). Local governments in the United Kingdom, previously audited by public auditors and by private audit firms, have been audited since 2010 by private firms only (Jones \& Caruana, 2015).

The Collegiate Model operating in Germany, the Netherlands, and Japan delegates maximum authority to a board with consensus decisions (Stapenhurst \& Titsworth, 2001). In Germany, the governmental audit is runned in the States, Cities, Municipalities and Counties. At the state level, the audit is done by an independent government body with full autonomy to define the scope of the work (i.e., the Legislative does not indicate what should be audited). Local governments (Cities, Municipalities and Counties) have their accounts audited annually by private firms, except the cities where the state audit organization is located, which are audited by it (Berger \& Heiling, 2015).

In the Napoleonic model, adopted by Brazil, France, Italy and Spain, the audit organization is not only autonomous but also distant from the Legislative (despite its auxiliary role). The main focus of the auditing is to verify the legality of the operations executed by the government; little attention is paid to the efficiency of actions. Their auditors tend to have legal background. The audit in this model subsidizes the legislature with technical opinions of government accounts. The audit organization has two layers, a technical one and a judging one. The judging layer, which is the organization's last decision on all subjects, should vote on technical recommendations and could penalize civil servants, public sector managers and firms that contract with governments (Stapenhurst \& Titsworth, 2001).

In Brazil, regional audit organizations follow closely TCU formation. Each State in its Constitution provides for the establishment of its regional Court of Accounts. Unlike the Italian model, all external audit tasks of governments are performed by public servants hired with career stability in CAs. Therefore, it can be said that government audit organizations in Brazil hold the monopoly of auditing legality and performance in governments for purposes of external control. States or municipalities do not pay to be audited and the governors and mayors should not have interference over the agenda and scope of the audit.

\section{LITERATURE OF AUDIT QUALITY IN GOVERNMENTS}

The existing literature identifies three types of audit procedures performed by government audit organizations; they are (i) financial: related to the reliability of the financial statements; (ii) legality: related to compliance with laws; and (iii) performance or operational: related to the efficiency of the public resources usage (Santiso, 2007).

Financial audit reports are fundamental for the enforcement by the external control network on public administration, especially considering recent advances of public sector accrual accounting. The quality of financial audits performed by audit organizations would enhance the effectiveness of the control network in relation to offer coercion to governments. Audit quality is the joint probability of a particular auditor (i) detecting relevant breaches or misstatements in standards applied to financial statements and (ii) reporting such misstatements (DeAngelo, 1981). 
However, the quality of the audit is related to external factors, which audit organizations have no influence - such as political competition, alternation of power, and existence of well-defined legal mandate (Dye \& Stapenhurst,1998; Melo \& Pereira, 2013) - as well as internal factors, which they have potential control or interference. Among the internal factors are the independence of auditors, the best application of the available budget to their activities and the qualified staff (Dye \& Stapenhurst, 1998; Portal, 2011). Flaws in these factors lead to a decrease in audit quality and, consequently, to the minor effectiveness of the audit organization and the entire control network.

The independence of the audit body is made up of its organizational independence and the operational independence of its auditors. The first concerns the non-interference of other spheres of government in the body's mandate and the exempt action of the Councilors (in the case of the Napoleonic model) in relation to mayors, governors, federal judges. The second type of independence concerns the audit process itself to choose the audit objective and what will be reported (Dye \& Stapenhurst, 1998; Power, 1997), without interference from the auditee, whether exercised directly in the auditors or by means of requesting the highest hierarchical positions of the audit organization itself to interfere in favor of the auditee.

One of the remedies to the loss of independence of auditors is the periodic rotation, which is considered essential by the INTOSAI code of ethics (ISSAI 30) and by the Government Auditing Standards applicable to external control in Brazil, published by Rui Barbosa Institute in 2010. The non-repetition of the auditing team (rotation) that recently acted in the same entity would increase the objectivity and accuracy of the reports issued.

However, the discussion on rotation is broad and has pros and cons to such practice. The argument in favor of rotation is the consequent reduction of the auditor's catch potential by the auditee. The recursion of audit-auditee interaction develops relational trust in the pair (Rousseau, Sitkin, Burt \& Camerer, 1998), which reduces the independence of reporting nonconformities through the bonds of friendship developed. On the other hand, since audit quality is lower at the beginning of the relationship because the auditor is not aware of the auditee's activities (Francis, 2004), low recursiveness inhibits learning development and hinder audit quality and depth.

In turn, the recursiveness could come from the greater geographical proximity between auditor and auditee, with positive effects to audit quality. Informal conversations with auditees would bring crucial information and greater use of on-site visits at lower cost, as well as obtaining local media information (newspapers, radios, and local TVs) would broaden the possibility of developing specific knowledge (Choi, Kim, Qiu \& Zang, 2012). In an era prior to the internet boom, Carcello, Hermanson, and McGrath (1992) pointed out that greater involvement between auditor and auditee and a greater number of on-site audits were among the ten most relevant factors for audit quality.

Unlike the private sector, where the size of the audit organization is significant because of the auditors' harmful dependence on the revenue of a particular customer or group of clients (DeAngelo, 1981), governmental audit organizations don't have necessarily their revenues generated by the provision of services in the public sector. When they do, they can still benefit from the service monopoly. In the case of Brazil, CA revenues come from the State itself and are not associated with the volume or quality of the services provided. Thus, the auditor does not suffer pressure from their directors to preserve contracts with clients. However, there is still some degree of dependence between CAs and the State Government, which has the discretion to define their budget.

Another relevant aspect for the autonomy of auditors is the possible promotion to higher positions of the audit organization, such as management positions, by the influence of high officials of the central government or local government with the Councilors. This would reduce the independence of the audit director even though he/she had a permanent position (tenured). Finally, a greater politicization of the judging layer (in Napoleonic models) could lead to less autonomy of the technical layer if there were interference in the operational procedures or discretionary allocation of resources for certain projects supported by the technical layer (such as innovation of audit procedures and procedures, manuals, new information systems etc.), but which may not have support from the judicial branch.

Even with organizational independence assured for CA, constraints on audit capacity or teams with lower capabilities reduce audit quality (Dorotinsky \& Floyd, 2004). The technical capacity to perform audits depends on the technology and procedures used to execute the audit work, on the scope of the data analyzed, on the size of the teams, on the training and the experience of the auditors (DeAngelo, 1981; Isaksson e Bigstein, 2012). Auditors would be continually encouraged to improve their skills in the areas of expertise through a combination of formal education in the area, continuous training and hands-on experience (Stapenhurst \& Titsworth, 2001). Accounting and statistics bachelor degrees are relevant for financial auditing practices (Portal, 2011). 
The size of the teams determines the total of hours allocated to auditing jobs and consequently the audit quality. As the greater the audit effort (hours of work), the greater is the probability that the auditor will find nonconformities in accounting statements (Caramanis \& Lennox, 2008), the total number of staff hours available for the audit will affect the overall quality of the process (Deis \& Giroux, 1992; Portal, 2011).

Regarding the technology used, the use of Computer Assisted Audit Tools (CAAT), or Data Reporting Systems, in the collection, storage and pre-processing of accounting data increases the effectiveness of the auditing process (Braun \& Davis, 2003) by analyzing large quantities of data in a shorter period of time. Thus, the degree of automation of CAs would affect the hours-audit ratio used in audit work.

However, it is not only the presence of such factors that would lead to a better audit, but their combined presence, coupled with the context in which they operate. This notion of fitness between context and structure (organizational fit) was applied by Gupta, Dirsmith and Fogarty (1994) to the teams of the General Accountability
Office in the United States. The Office adjusted of its teams' control and coordination to the external environment and the technical nature of the audit task. Such organizational alignment approaches through contingency theory or institutional theory have been applied to explain the responses of organizations in the search for better performance, either with the adequacy to environmental demands (contingency fit) or the search for legitimacy in relation to the stakeholders (institutional fit) (Van de Ven \& Drazin, 1985). Thus, fit or alignment is seen as the congruence of organizational responses (technology, structure, processes) to the environment and institutional context.

Several combinations of alignment may have similar and superior performances depending on the context, which has been called by Van de Ven and Drazin (1985) of isoperformance. As adaptation is a dynamic process, given the constant environmental change (Zajac, Kraatz $\&$ Bresser, 2000), the organization operates under a semiadequacy level (Donaldson, 2001) is repeatedly challenged in its structure and organization.

\section{METHODOLOGY}

This study is based on (i) thematic analysis of the literature and content analysis of public documents of CAs and (ii) interviews. First, the thematic analysis suggested by Tranfield, Denyer and Smart (2003) was carried out, categorizing the audit quality determinants identified in the external audit literature of governments, based on a systematic review of empirical studies on Accounting, Administration and Public Finance journals. The thematic analysis of empirical studies identified internal factors (independence and technical capacity), which were divided into the following formative characteristics of the audit organizations:

1. Operational independence. It refers to the autonomy of the auditors in selecting the best criteria for performing the audit work and being less subject to actions that would lead them to not report identified misstatements. Such independence is the existence of institutionalized periodic rotation on audit team.

2. Human Resources and Organization. It is the part of the internal capacity related to the acquisition and development of technical skills necessary for the audit work and the organization of these capacities (human capital) in specialized teams. For the same budget, the CA could choose how to apply available resources to expand the number of specialized auditors and how to geographically allocate them to regional offices or concentrate them in a single headquarter.

3. Audit Processes. It is the technical capacity expressed in the processes used to carry out the audit. Examples are on-site auditing in all audited entities and the automation of audit work routines.

4. Process of Data Collection. Since audit organizations need to break the asymmetry of information regarding the transactions carried out by their auditees, this internal capacity deals with the IT strategies employed by the CA to access the accounting and budgetary data of the audited entities. As example, the recent continuous investments made in the Data Reporting Systems by all CAs in Brazil .

Although the research aims to analyze the Courts of Accounts the diversity in relation to their internal factors as explained above, such organizations are circumscribed to a context, which denotes external factors to be taken into account:

5. Jurisdiction, foundation and annual budget. While the jurisdiction was given by the Constitution of the State of the Federation in which the CA operates, its budget is defined yearly by the Legislative Assembly. Notwithstanding this factors which can vary in the present time, a historical aspect is impressed by the year of foundation of each court. The norms, values and structures 
usually adopted and the regulation in force that year will impress how the court was organized and should operate. It can change through time, but always some path dependence remains. This starting point was not chosed by the current counselors and directors in chief.

Next, we conducted interviews to observe the determinants of the CAs' formative characteristics We contacted the correspondent ombudsman of each 33 CAs, which led to a positive participation response of 18 CAs (54\% of CAs), from all regions of Brazil, with different sizes regarding the number of audited entities. This represents the plurality of context studied. The region less represented in the survey is the Midwest, and the most represented are South and Southeast, with $40 \%$ and $67 \%$ of CAs interviewed respectively. The interviews were made by telephone between April and December 2015, with auditors (called 'Analistas de Controle Externo' in Portuguese) and directors of Information Technology (IT). As the analysis is focused on the internal factors, observed with greater precision by the technical layer, it was decided not to interview Counselors (political layer).

A semi-structured interview protocol was adopted, divided in the formative characteristics mentioned. After scheduling the interview, the questions was sent to the respondent for their prior preparation. Some interviewee preferred as a first step to send the answers by email and then be contacted by phone to confirm answers or make any supplements. On average, the interviews lasted 45 minutes. Interviewees in general have been working for more than 10 years in the CA (maximum of 28 years, minimum of 4 years), and $75 \%$ of them had a coordination position (auditor in chief). We counted on the recordings of the interviews to perform the content analysis and to inductively identify the determinants in each training characteristic.

It can be said that each characteristic was unfolded in determinants, because its presence led to it. As the determinants were identified inductively, and no prior knowledge of the determinants was found, respondents were contacted more than once to confirm answers or to add information. The determinants are represented in the columns of Table 1, for each of the formative characteristics. It should be noted that those mentioned in the table do not form an exhaustive list. As an example, the automation of audit work routines did not emerge as a relevant aspect, since CAs are generally at an early stage in the issue. Finally, when available, documents such as annual activity reports for the year of 2014, audit manuals and the Data Reporting Systems manuals available on CAs websites served as a complement and triangulation in relation to the data (Denzin \& Lincoln, 2005) obtained through interviews.

\section{THE DIFFERENT SETTINGS OF THE COURTS OF ACCOUNTS}

The institutional development of CAs is associated with the institutional changes of the country and the states (Loureiro et al, 2009) over the 100-year time window of their creation (1891 - 1991). A priori, temporal concentration in its implementation is not identified, since there are CAs settled under the aegis of all Federal Constitutions (except 1937). These Federal Constitutions, and most recently constitutional amendments and complementary laws (such as the LRF), change the legal mandate of CAs (space and scope to act), impacting their independence (in the event that audit mandates are not well defined, especially when laws are new). In addition, such changes impact the ability of CAs to change the scope of their audits in order to fulfill new legal mandates. The budget allocated to each CA may be protected by some rule, such as the link to state revenue applied by Mato Grosso and Santa Catarina states. In non-ruled cases, the CA budget could be subject to political bargaining, as the state government may reduce the CA budget in approving the bill for the year's budget. The more pressured and uncertain the budget available to the CA is, the more it can reduce its organizational independence to bargain resources, restricting auditing efforts and investments in training and technology, directly impacting the audit quality.

A first characteristic that is of clear impact in the differentiation of the structure of the Courts of Accounts of States and Municipalities in Brazil is the jurisdiction coverage. The coverage highlights two major groups: (i) those courts which audit the accounts of a single municipality; and (ii) those which audit the accounts of several municipalities belonging to the geographical location of a specific State. Examples of this characteristic are the index of total budget per audited entity and the eventual logistical complexities to run the job The 5,569 Brazilian municipalities, 26 states and the Federal District should be audited by 33 CAs. According to Figueiredo, Melo and Pereira (2005), in 2005 there were 22,166 auditee entities for 33 CAs to carry out the examination of accounts. Such number comprises agencies and secretaries from the Executive branch and local legislative councils. 
The first group of CAs which audits a single municipality is listed at the bottom of Table 1 . These CAs only audit the capital or the state government, in addition to the specific case of the Federal District. Their teams are geographically centralized and have a higher ratio of auditors by audited entities (ie, all bodies from executive and legislative branches). Still, such CAs deals with a single mayor and a single local legislative council, having greater recurrence and frequency of interactions with them. In terms of audit quality, auditors can achieve greater specialization given the proximity of teams based, generally, geographically close to their auditees in the capital city. In these cases, the number of agencies to be audited is larger and also involves larger budgets. As their jurisdictions are Capitals or state governments, auditors deal with issues that do not appear or are less frequent in other municipalities, such as joint initiatives, PPPs and complex contracts, so that greater specialization is desirable. However, the frequency of interactions can reduce the autonomy of technical auditors and their operational independence.

CAs of single jurisdiction do not gain scale when developing their own data reporting systems (DRS). In order to have access to the data of the auditee, they entered into an agreement of full access to the Integrated Financial Management Information System (IFMIS) of the local jurisdiction, obtaining a more timely and detailed data collection. Thus, in the absence of their own DRS, they should seek other means of issuing automatic alerts and make prior analyzes on tax aspects, for example. Finally, these CAs have a differential resource pressure in relation to the others, given the less difficulty of logistic access to the various organs.

The second group of CAs, listed at the top of Table 1, brings together those who have multiple municipalities in its jurisdiction. Each of these CAs relates to several mayors, local legislative councils, and independent governmental agencies bodies. Geographical dispersion is an important element and impacts the costs of on-site auditing. The two combined effects, multi-jurisdictions (audited municipalities) and geographic dispersion, bring incentives and productivity gains to data collection automation (Data Reporting Systems - DRS). The DRS acts to reduce the asymmetry of information between the auditee and the CA, increasing the frequency of access to the accounting registering (as can be seen in Table 1) since these CAs do not directly access the IFMIS of the audited entity. The greater the reduction in information asymmetry, the greater the potential of audit quality. Three factors that result from the development of DRSs end up boosting the productivity of audit work in the CA. The greater periodicity, the greater level of detail of the data collected (analytical data, rather than just synthetic - as budget balance). Sending previous analyzes to the auditors generate efficiency gains (audit hours) and audit quality.

The periodic rotation of audit team institutionalized by internal norms exists in few CAs, contrary to the best practices promoted by INTOSAI. In the others, the rotation is occasional, resulting from the replacement of an auditor promoted to the coordination positions, or at the auditor's own request. Rotating associated with on-site auditing leads to less possibility of avoiding misstatements - auditors and auditees may not feel secure in performing activities that exceed the ethical limits of their professions. The rotation encourages municipalities to develop its accounting information systems and to improve accounting policies and innovate in budgetary and risk management, since they do not know ex ante the auditor who will audit on-site. On the other hand, the international literature points out that the recursiveness of the relationship between auditor and auditee would lead to the sharing of knowledge and the influence of the auditor on best practices in the audited bodies. This would allow the development of learning about the auditee.

Learning is an important intangible capital for the auditor in medium and large municipalities, given the greater presence of independent governmental agencies and greater need for specialization/learning in these bodies. Such an effect would be smaller in less complex, small municipalities (e.g., fewer audit hours to identify problems that are more serious). The number of auditors per organ varies from less than 1 auditor to 10 organs (Goiás State) up to 1.3 auditors to 1 organ (Sergipe State). The greater relationship between a body and an auditor can lead to both on-site audit restriction, which combined with a DRS restricted to synthetic data, reduces the scope of the audit, how much can lead to a less reclusive auditauditee contact; this would be mitigated by rotating auditors.

Some CAs distribute audit teams to regional offices, regardless of the number of jurisdictions. Before the automation of the DRS, the resource was used to increase speed of procedure since the jurisdictional ones did not have to send their documents until the state capital, where headquarters of the CA are usually located. In the case of the Sao Paulo State CA, the historical motivation for such organization was to generate a greater physical proximity with the audited entities. Currently, regional offices are not only an operational base of auditors who go to the field (on-site audit); as they are stable in structure and 
teams, they develop their own institutional variation. It reduces the uniformity of audit processes, even with defined and shared audit work protocols.

Another form of team organization is the use of specialized offices ('inspetorias' in Portuguese). These are specialized audit departments specific to (i) a type of public service delivery, like specifics entities as health, education, state companies for water supplying or public transport, or (ii) by geographic area. Additionally, some CAs have specialized offices to audit just the state capital city or the state government. The segregation in regional offices or specialized offices imposes a reduction of rotation because it increases the chance of recursiveness in the relation between auditee and auditor.

The requirement of training in Accounting for auditors is not a consensus. There was no such requirement in the last hirings held in states of Pará, Rio Grande do Sul and Acre. All of them occurred after the announcement of the convergence of national accounting rules to international standards. The low qualification or non-specialization of the auditors in accounting background can be alleviated by the use of automated data reporting systems and consequent prior analyzes issued by the CA to auditors and jurisdictions in a standardized manner. However, the automated DRS would not resolve the audit of the accounting process itself. Without accounting background, the auditor is not able to judge the adequacy of the accounting policies implemented in the municipalities, even in Courts that access municipalities' detailed data. In order to do this type of audit, the auditor must effectively analyze the accounting policy (regarding the registration, recognition, and measurement) used.

A formal training in accounting (as a bachelor degree for instance) is relevant to the execution of the auditing jobs for both cases of CAs, with only one audited entity or several. The fact that the auditor does not have prior accounting knowledge inhibits specific misstatements in accounting topics to be detected. Therefore, the auditor often is restricted to a compliance auditing. The maximum number of auditors graduated in accounting was $26 \%$ and the minimum was $13 \%$ (data not shown in the table).

The audit process also varies. For the most part of them, it is conducted as a "legality audit", in which CAs verify entities' compliance with budget legislation and fiscal parameters from FRL. In general, auditing techniques go through physical verification, inspection of documents and records, such as accounting journal entries. There is still observation of the activity performed in the entity, interviews and calculation conferences. In financial auditing, examples are the correctness on accounting policies used to record transactions such as expenditures and revenues.

Only two cases among CAs of several jurisdictions carry out on-site audits in all entities. CAs in general prefer to audit on-site part of entities they are responsible each year, consequently part of them are no audited that year. There is no clear relationship between the available resources (CA's budget per total auditees) and volume of auditing jobs (number of audits per total auditees), what brings the question whether the potential dependence on resources would be a justification to reduce on-site audits. In the case of Courts of Accounts that do not perform yearly on-site auditing to all audited entities, the prior selection of which entities will be audited on-site occurs (i) via random sampling or (ii) by criteria pre-established in a risk matrix or (iii) a combination of the above. The risk matrix directs auditing efforts to cases that show chances of higher impact irregularities. The effectiveness of the matrix is in the parameters they use; these will "pull" the cases with irregularities to be considered in the sample. When the interviewee wanted to describe the applied risk matrix, the following indicators were presented: (i) previous address on misconduct in public management and rejection of accounts; (ii) how long time ago the last auditing was run; and (iii) materiality (e.g., budget size). With the computerization and use of DRS, any errors identified in the computerized rendering of accounts allow constant updating of the risk matrix. In addition, they are the justification of the CA for public managers.

While the exclusive use of random sampling of selected entities to be audited may leave material and relevant potential auditees outside the analysis, the exclusive use of risk matrix may condition that, in the long run, smaller municipalities with lower budgets and no history of rejection have a low probability of being audited on-site. With the low risk of being audited, the entity may carry out activities that are not in accordance with good public management practices. The ideal would be combine a random sampling to risk matrix selection to states where there is no annual on-site auditing to all entities. This makes all entities potentially auditable in the same year. 
Table 1 - Formation characteristics of the Courts of Accounts

\begin{tabular}{|c|c|c|c|c|c|c|c|c|c|}
\hline \multirow{2}{*}{ State } & \multicolumn{4}{|c|}{ Jurisdiction, foundation and budget } & \multicolumn{2}{|l|}{$\begin{array}{l}\text { Operational } \\
\text { independence }\end{array}$} & \multicolumn{2}{|c|}{ Process of Data Collection } & \multirow[b]{2}{*}{$\begin{array}{l}\text { Previous } \\
\text { analysis }\end{array}$} \\
\hline & Jurisdiction over ${ }^{(i)}$ & Year of creation & $\begin{array}{c}\text { CA budget } \\
\text { (\% state budget) }\end{array}$ & $\begin{array}{l}\text { Budget / audited entities } \\
\text { (thousands of Brazilian Reais) }^{(i)}\end{array}$ & $\begin{array}{l}\text { Auditors } \\
\text { Rotation }\end{array}$ & $\begin{array}{l}\text { Access to the IFMIS } \\
\text { of the jurisdiction }\end{array}$ & $\begin{array}{l}\text { Data } \\
\text { granularity }\end{array}$ & $\begin{array}{l}\text { Accounting Data } \\
\text { collection periodicity }\end{array}$ & \\
\hline TCE-SE & $S+M$ & 1969 & 1.44 & 1,225 & Standardized & No & Synthetic & Monthly & . \\
\hline TCE-RR & $S+M$ & 1988 & 1.58 & 3,706 & Occasional & No & Analytical + FAE & Monthly & . \\
\hline TCE-RO & $S+M$ & 1983 & 0.01 & 11 & Standardized & No & Synthetic & Monthly & Yes \\
\hline TCE-RS & $S+M$ & 1935 & 1.02 & 748 & Occasional & No & Synthetic & Bimonthly & Yes \\
\hline TCE-PR & $S+M$ & 1947 & 0.77 & 570 & Occasional & No & Analytical & Monthly & Yes \\
\hline TCE-AC & $S+M$ & 1987 & 0.91 & 1,976 & Occasional & No & Analytical + FAE & Monthly & Yes \\
\hline TCE-MG & $S+M$ & 1935 & 0.53 & 390 & Standardized & No & Synthetic + FAE & Monthly & Yes \\
\hline TCE-SP & $S+M$ & 1921 & 0.25 & 595 & Occasional & No & Synthetic + FAE & Monthly & Yes \\
\hline TCEM-BA & M & 1989 & 0.33 & 176 & Standardized & No & Synthetic & Monthly & Yes \\
\hline TCEM-PA & $M$ & 1980 & 1.32 & 1,320 & Occasional & No & . & Quarterly & \\
\hline TCEM-GO & M & 1977 & 1.04 & 692 & Standardized & No & Analytical + FAE & Monthly & Yes \\
\hline TCEM-CE & $M$ & 1954 & 0.01 & 5 & Occasional & No & Analytical + FAE & Monthly & Yes \\
\hline TCM-SP & $\mathrm{C}$ & 1968 & $0.43^{\text {(iv) }}$ & 179,666 & Occasional & Yes & Total & Daily & Yes \\
\hline TCM-RJ & $\mathrm{C}$ & 1980 & $0.93^{\text {(iv) }}$ & 176,691 & Does not exist & Yes & Total & Daily & . \\
\hline TCE-PA & $E$ & 1947 & 1.32 & 27,155 & Standardized & Yes & Total & Daily & . \\
\hline TCE-CE & $E$ & 1935 & 0.01 & 159 & Does not exist & Yes & Total & Daily & . \\
\hline TCE-BA & $E$ & 1915 & 0.33 & 29,155 & Occasional & Yes & Total & Daily & . \\
\hline TC-DF & FD & 1960 & 0.01 & 402 & Occasional & Yes & Total & Daily &. \\
\hline
\end{tabular}

Notes: (i) S + M: Municipalities and State; M: Only municipalities; C: Capital; S: Only State; FD: Federal District. (ii) Expenses paid in the external control function, except in

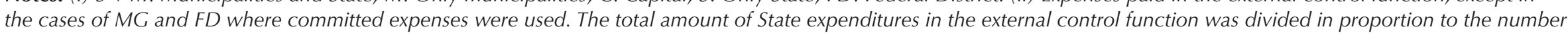
of audited entities to the Municipal Court of Accounts and to the State Court of Accounts in the states of PA, GO, CE and BA, since the teams and the structure are employed in both instances, data from 2013. (iii) "Synthetic" data refers to the sending of balances of the main budget accounts. "Analytical" data refers to the sending of accounts that

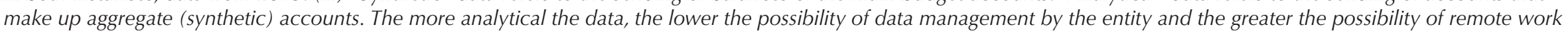

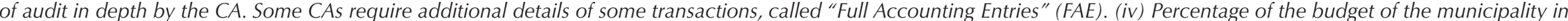
question (and not of the State). (v) Values not reported by the CA are marked with ".." 
Table 1 - Formation characteristics of the Courts of Accounts (continuation)

State

$\begin{array}{ccc}\text { Audited } & \begin{array}{c}\text { Number of } \\ \text { municialities }\end{array} & \begin{array}{c}\text { Number of } \\ \text { entities (a) }\end{array} \\ \text { and states } & \text { auditors (b) }\end{array}$

\section{Auditors \\ / Audited \\ Regional Specialized
Offices Offices} Entities (b/a) $\begin{array}{cc}\text { Year of the last } & \text { Auditors' Accounting } \\ \text { competitive } & \text { Bachellor as }\end{array}$

hiring process

for auditors ${ }^{(i)}$

$\begin{array}{ccc}\begin{array}{c}\text { Bachellor as } \\ \text { requirement for } \\ \text { mpetitive examining } \\ \text { and hiring process }\end{array} & \begin{array}{c}\text { On-site } \\ \text { audit in all } \\ \text { entities? }\end{array} & \begin{array}{c}\text { On-site } \\ \text { audits/ } \\ \text { audited } \\ \text { entities }\end{array} \\ & & \end{array}$

Reasons for not auditing them on-site ${ }^{(i i)}$
Criteria for choosing which entity to audit ${ }^{(i v)}$

\begin{tabular}{|c|c|c|c|c|c|c|c|c|c|c|c|c|c|}
\hline TCE-SE & 104 & 75 & 135 & & 1.30 & 0 & No & 2011 & Yes & Yes & 1.75 & $\mathrm{NA}$ & $\mathrm{NA}$ \\
\hline TCE-RR & 85 & 15 & 92 & (i) & 1.08 & 0 & Yes & 2006 & Yes & No & 0.38 & U & . \\
\hline TCE-RO & 199 & 52 & 107 & & 0.54 & 5 & Yes & 2013 & Yes & No & 0.43 & OC & $M$ \\
\hline TCE-RS & 1,269 & 497 & 519 & & 0.41 & 9 & Yes & 2011 & No & No & 0.98 & $\mathrm{OC}, \mathrm{C}$ & $M$ \\
\hline TCE-PR & 1,330 & 399 & 486 & & 0.37 & 0 & Yes & 2011 & Yes & $\mathrm{No}$ & 0.01 & U & $M$ \\
\hline TCE-AC & 207 & 22 & 67 & (i) & 0.32 & 0 & Yes & 2010 & No & No & 0.83 & $\mathrm{~L}, \mathrm{OC}$ & $\mathrm{L}$ \\
\hline TCE-MG & 2,324 & 853 & 669 & & 0.29 & 0 & Yes & 2006 & Yes & No & 0.15 & $\mathrm{U}, \mathrm{C}$ & $M$ \\
\hline TCE-SP & 3,021 & 645 & 614 & (i) & 0.20 & 20 & Yes & 2011 & Yes & Yes &. & NA & NA \\
\hline TCEM-BA & 954 & 417 & 201 & (i) & 0.21 & 21 & Yes & 2008 &. & No & 0.03 &. & $\mathrm{~A}+\mathrm{M}$ \\
\hline TCEM-PA & 630 & 144 & 80 & (i) & 0.13 & 2 & Yes & 2009 & No & No & 0.02 &. & $M$ \\
\hline TCEM-GO & 2,094 & 246 & 168 & & 0.08 & 0 & Yes & 2012 & Yes & No & 0.06 & OC & $M$ \\
\hline TCEM-CE & 582 & 184 & 187 & & 0.32 & 7 & Yes & 2006 & Yes & $\mathrm{No}$ & 0.24 & $\mathrm{U}$ & $M$ \\
\hline TCM-SP & 21 & 1 & 142 & & 6.76 & 0 & $\mathrm{No}$ & 2015 & Yes & Yes & 8.19 & $\mathrm{NA}$ & $\mathrm{NA}$ \\
\hline TCM-RJ & 53 & 1 & 313 & & 5.91 & 0 & Yes & 2010 & No & Yes & 1.94 & $\mathrm{NA}$ & $\mathrm{NA}$ \\
\hline TCE-PA & 90 & 1 & 180 & & 2.00 & 0 & . & 2012 & Yes & Yes & 0.23 & $\mathrm{NA}$ & NA \\
\hline TCE-CE & 100 & 1 & 105 & & 1.05 & 0 & Yes & 2015 & Yes & No & 0.80 &. & $\mathrm{~A}+\mathrm{M}$ \\
\hline TCE-BA & 380 & 1 & 323 & (i) & 0.85 & 0 & Yes & 2013 & No & No & 0.21 & OC & $\mathrm{A}+\mathrm{M}$ \\
\hline TC-DF & 82 & 1 & 269 & & 3.28 & 0 & . & 2013 & $\mathrm{No}$ & $\mathrm{No}$ & 0.61 & . & $M$ \\
\hline
\end{tabular}

Notes: (i) Value based on the average number of auditors per total number of servers in the CAs where data was available. (ii) Auditors are 'Analistas de Controle Externo' in Portuguese . (iii) U: No utility is observed; C: Cost; CO: Low Operational Capacity; L: Logistics; NA: Does not apply. (iv) A: Random sampling; M: Risk matrix; L: Logistics; A + M: Risk Matrix and Random Sampling; NA: Does not apply. (V) The number of on-site audits was obtained in the last activity report made available by the CAs website and includes several themes in the same visit, such as the financial one. (vi) Values not reported by the CA are marked with ".".

Source: Developed by authors. 


\section{DISCUSSION AND IMPLICATIONS FOR LITERATURE IN PUBLIC FINANCE}

As observed, the structure of the CAs and the range of the auditing process vary significantly in the cases we analyzed. The question is how much this affects audit quality. The previous literature indicates that if an organization chooses structure, internal organization and technology in such way misaligned to the context (contingencies) or to the current institutional set (regulation, expectations of stakeholders), its performance happens to be lower. Thus, the different responses of CAs to their context will impact the performance of their audit. The first identified group (CAs of a single jurisdiction) has a context in which the financial audit is threatened by the independence of the courts due to the proximity to the auditee. Even with rotation, the smaller number of audited entities and geographical proximity increase the likelihood of an auditor maintaining a recursive relationship with the same team of the audited government's civil servants. The benefits of expertise can overcome the threat of low independence to report nonconformities. On the other hand, the high number of auditors and full access to financial data through the use of the IFMIS of the municipality positively impact the technical capacity of auditing in this group.

In the context of the identified (second group multimunicipalities CAs), there is a greater potential for enhancing the independence of the auditor due to the use of auditor rotation (even if informal) combined with the greater number of audited entities. However, there is less specialization of the auditor in relation to the particularities of a particular auditee when the rotation is heavily used. The loss of specialization in this case could be reduced with the use of subject-based specialized offices as an alternative source of expertise, ensuring higher audit quality. The lower number of auditors by the jurisdictional entity higher the potential to justify the automation of the data collection process. Despite the differences in the collection process observed in CAs (for example, synthetic or analytical accounting data), greater automation would release more working hours for on-site audits.

Currently there are CAs that access through DRS information monthly of the entities with greater detail, emit previous alerts and audit only part of them on-site, based on objective criteria of a risk matrix (like Goiás and Paraná states), while São Paulo continues to audit all entities annually, with occasional rotation. On the other hand, some CAs receive data with low detail and audit on-site part of them annually with rotation, with selection by Risk Matrix (for example, RS and RR).
The discussion of the results points out that to capture the effect of CAs on the performance of governments, metrics that control the adequacy of the configuration of CAs to their context are necessary, capturing with the vector "coercion by the quality of the audit" with less trouble.

The differences identified in the CAs can be used by the literature in two perspectives: to (i) explain the different configurations of CAs; and (ii) what are the impacts of setting up a CA regarding quality of auditing produced by its auditors. One configuration would be the combination of organizational characteristics gathered as responses of CAs considering the demands, resources available and the contingent and institutional factors in which they operate. The configuration is developed over time, with a certain effect of path dependence on previous choices and in response to new demands that significantly increased the scope of action in fiscal supervision of CAs (for example, LRF). In the first perspective, the alignment to the context would explain organizational choices that were preferred in the creation and restructuring of CAs. In the second, the alignment of the CA configuration would explain the higher audit quality.

If the organization's performance is superior when it is aligned with the context in which it operates, similar configurations will have similar effects if they operate in similar contexts. Similar contexts are the variables that affect the process of external control and that fall short of the CAs discretion, such as: level of attention of the legislative to the budget issue, cooperation between executive and legislative, civil society performance, degree of structuring of systems of information and internal audit in entities, among others. Isolated features that may be detrimental to audit quality if combined with others lead to an opposite effect (joining nonrotation with automated alert issuance).

The effect of report quality on the Napoleonic model occurs first in the court's judging stage. Counselors may fail to fully or partially follow the recommendation of the technical audit report, for example for a decision on the municipality's accounts. A low technical capacity configuration reduces the chances of irregularities being pointed out by the auditors in their entirety, or increases the chances that the technical reports present poor technicalities. In both cases, the judicial stage may question the technical report.

The decision on the accounts of municipalities depends on other factors external to the CA to have potential 
enforcement, such as the propensity of the Chamber to release the mayor's term of office and favorable judgments to the decisions of the CAs in the Judiciary. However, acts of public managers will be changed to legality and efficiency as governments and their managers are punished when they fail to comply with regulation. Such punishment would result in the payment of fines, imprisonment or loss of political capital, such as becoming ineligible for a period or having a weak reputation. For attribution of related penalties, the audit report is the basis for constructing justifications for punishing the public manager in all cases, but does not guarantee the process. Thus, the use of isolated set of characteristics as a proxy for audit quality or CA enforcement should be done with caution, since neither the quality stems from the isolated characteristics nor are they sufficient to coerce governments.

Auditing can lead organizations to improvements and innovations (Power, 1997). Thus, although the CA does not have coercion to generate further incentives, its performance may lead to organizational improvements in the audited entities, which, if perpetuated, can strengthen mechanisms of fiscal governance indirectly. Similarly, demands for greater frequency and detail in the sending of data via DRS and requirement of justification impel the improvement of administrative, budgetary, accounting and internal control processes.

\section{FINAL CONSIDERATIONS}

This research analyzed different configurations of Courts of Accounts that act at a regional level in Brazil, supervising and supporting the development of the financial management cycle in states and municipalities. Differences such as size and specialization of teams, automation of accounting data collection, different criteria for selection of on-site audit cases and recursiveness in the audited-auditee relationship, combined in a working context, would be associated with the court's quality audit. These differences remain the same even after the Atricon and IRB actions, seeking the harmonization of some practices in CAs (such as NAGs and PROMOEX).

Many differences are environmental responses by the audit organization to conditions to which it is exposed, such as budgetary constraints, geographic dispersion and number of auditees. The financial audit procedures performed by CAs become increasingly relevant with the process of convergence to international accounting - accrual accounting. The non-uniformity of these procedures would undermine the translation of this reform to entities all over the country, mitigating the standardized dissemination of practices. This would impact the consolidated statements in the Whole of Government Accounts (BSPN, in Portuguese). The discussion on the creation of a National Council of Courts of Accounts points to this need for uniformity.

This discussion draws attention to future Public Finance research that, regardless of the movement of harmonization of procedures, CAs should not be interpreted as a set of uniform enforcement units until such variations in the effect of CAs as mechanisms of coercion to fiscal regulation and other reforms are mitigated. Although the external audit had a similar quality among regional government audit organizations in Brazil, a direct association between the quality of the external audit and the extent to which the municipalities follow or not the Court's recommendations should not be made, since coercion also depends on other contextual factors. 


\section{REFERENCES}

Andrews, M. (2007). What would an ideal PFM system look like?. In Shah, A. (Coord.). Budgeting and Budgetary Institutions. (pp. 359-383). Washington, D.C.: World Bank.

Andrews, M. (2013). The Limits of Institutional Reform in Development: Changing Rules For Realistic Solutions. (1. Ed.) New York, NY: Cambridge University Press.

Arantes, R. B., Abrucio, F. L., \& Teixeira, M. A. C. (2005) A imagem dos Tribunais de Contas subnacionais. Revista do Serviço Público, Brasília, Brazil: Enap, 56(1), p. 57-85.

Berger, T. M., \& Heiling, J. (2015). Public Sector Accounting and Auditing in Germany. In Brusca, I; Caperchione, E.; Cohen, S.; \& Manes Rossi, F. (Coord.). Public Sector Accounting and Auditing in Europe: The challenge of harmonization. (pp. 93107). London, UK: Palgrave Macmillan.

Braun, R. L., \& Davis H. E. (2003). Computer-assisted audit tools and techniques: analysis and perspectives. Managerial Auditing Journal, 18(9), p. 725 - 731.

Campos, E., \& Pradhan, S. (1996). Budgetary Institutions and Expenditure Outcomes: Binding Governments to Fiscal Performance, Policy Research Working Paper 1646, The World Bank, Washington.

Caramanis, C., \& Lennox, C. (2008). Audit effort and earnings management. Journal of Accounting and Economics, 45(1), p. 116-138

Carcello, J.V., Hermanson, R.H., \& McGrath, N.T. (1992). Audit Quality Attributes: The Perceptions of Audit Partners, Preparers, and Financial Statement Users. Auditing: A Journal of Practice and Theory, 11(1), p. 1-15.

Choi, J., Kim, J., Qiu, A. A., \& Zang, Y. (2012) Geographic Proximity between Auditor and Client: How Does It Impact Audit Quality?. Auditing: A Journal of Practice \& Theory. 31(2), p. 43-72.

Deangelo, L. E. (1981). Auditor Size and Audit Quality. Journal of Accounting and Economics. 3(3): 183-199.

Deis, D. R., \& Giroux, G. A. (1992). Determinants of Audit Quality in the Public Sector. The Accounting Review, 67(3), $462-479$.

Denzin, N. K., \& Lincoln, Y. S. (2005). The SAGE handbook of qualitative research. Thousand Oaks: Sage Publications.

Donaldson, L. (2001) The Contingency Theory of Organizations. Sage, Thousand Oaks, CA.

Dorotinsky, W., \& Floyd, R. (2004). Public Expenditure Accountability in Africa: Progress, Lessons and Challenges. In B. Levy and S. Kpundeh (coord.). Building State Capacity in Africa: New Approaches, Emerging Lessons. (pp. 179-210). Washington D.C: World Bank.

Dye, K. M., \& Stapenhurst, R. (1998). Pillars of integrity: the importance of supreme audit institutions in curbing corruption. Economic Development Institute World Bank.

Figueiredo, M., Melo, M., \& Pereira, C. (2005). Political and electoral accountability enhances accountability: a comparative analysis of courts of accounts in Brazil. In: International Congress of Lasa. Proceedings... San Juan, 2005.

Francis, J. R. (2004). What do we know about audit quality?. The British Accounting Review, 36(4), p. 345-368.
Gerigk, W., Clemente, A., \& Taffarel, M. (2010). O Impacto da Lei de Responsabilidade Fiscal sobre a gestão financeira municipal: o caso do Paraná. Revista de Educação e Pesquisa em Contabilidade, 4(3), p. 44-69.

Gupta, P. P., Dirsmith, M. W., \& Fogarty, T. J. (1994). Coordination and Control in a Government Agency: Contingency and Institutional Theory Perspectives on GAO Audits. Administrative Science Quarterly, 39(2), 264-284.

Isaksson, A., \& Bigsten, A. (2012). Institution Building with Limited Resources: Establishing a Supreme Audit Institution in Rwanda. World Development, 40(9), p. 1870-1881.

Jones, R., \& Caruana, J. (2015). Public Sector Accounting and Auditing in the United Kingdom. In Brusca, I; Caperchione, E.; Cohen, S.; \& Manes Rossi, F. (Coord.). Public Sector Accounting and Auditing in Europe: The challenge of harmonization. (pp. 219-234). London: Palgrave. UK.

Loureiro, M. R., Teixeira, M. A. C., \& Moraes, T. C. (2009). Democratização e reforma do Estado: o desenvolvimento institucional dos Tribunais de Contas no Brasil recente. Revista de Administração Pública, Rio de Janeiro, 43(4), p.739772.

Melo, M. A., \& Pereira, C. (2013) Making Brazil Work. (1 ed.) New York: Palgrave.

Melo, M. A., Pereira, C., \& Souza, S. (2014) Why do some governments resort to "creative accounting" but not others? Fiscal governance in the Brazilian federation. International Political Science Review, v. 35, n. 5, p. 595-612.

Moynihan, D. P., \& Andrews, M. (2010). Budgets and Financial Management. In Walker, R; Boyne, G.A.; \& Brewer, G.A. (coord.). Public Management and Performance: Research Directions (60-88). Cambridge, England: Cambridge University Press.

Portal, M. (2011). The determining factors for audit quality, the case of governmental financial statements audit. Comptabilité contrôle audit 17(1), p. 37-65.

Power, M. (1997). The Audit Society: Rituals of Verification. Oxford: Oxford Un. Press.

Rosa, C.P., Morote, R.P., \& Prowle, M. (2014) Developing performance audit in Spanish local government: an empirical study of a way forward, Public Money \& Management, 34:3, 189-196.

Rousseau, D., Sitkin, S.B., Burt, R.S., \& Camerer, C. (1998) Not so different after all: A cross-discipline view of trust. Academy of Management Review, 23(3), p.393-404.

Santiso, C. (2007). Eyes wide shut? The politics of autonomous audit agencies in emerging economies. CIPPEC Working paper. Buenos Aires, Argentina.

Santolin, R., Jayme Jr., F. G., \& Reis, J. C. (2009). Lei de Responsabilidade Fiscal e implicações na despesa de pessoal e de investimento nos municípios mineiros: um estudo com dados em painel dinâmico. Estud. Econ., São Paulo, 39(4), p. 895-923.

Santos, S. R. T., \& Alves, T. W. (2011). O impacto da Lei de Responsabilidade Fiscal no desempenho financeiro e na execução orçamentária dos municípios no Rio Grande do Sul de 1997 a 2004. Revista de Administração Pública, 45(1), 181-208. 
Speck, B. W. (2011). Auditing Institutions. In Power, T.; \& Taylor, M. (coord.). Corruption and Democracy in Brazil: The Struggle for Accountability. (pp 127-161). University of Notre Dame Press.

Stapenhurst, R., \& Titsworth, J. (2001). Features and Functions of Supreme Audit Institutions Washington, DC: World Bank PREM.

Tranfield, D., Denyer, D., \& Smart, P. (2003) Towards a methodology for developing evidence-informed management knowledge by means of systematic review. British Journal of Management, 14, p. 207-222.
Van de Ven, A. H., \& Drazin, R. (1985) The concept of fit in contingency theory. In Staw, B. M., \& Cummings, L. L. (coord). Research in Organizational Behavior. JAI Press, Greenwich, CT, 333-365.

Wehner, J. (2003) Principles and patterns of financial scrutiny: Public Accounts Committees in the Commonwealth, Commonwealth \& Comparative Politics, 41(3), 21-36.

Zajac, E. J., Kraatz, , M. S., \& Bresser, R. K. F. (2000) Modeling the dynamics of strategic fit: A normative approach to strategic change. Strategic Management J. 21(4), 429-453. 